\title{
Smart-use of fertilizers to manage spider mites (Acari: Tetrachynidae) and other arthropod pests
}

\author{
Katrina West ${ }^{1}$, Christian Nansen ${ }^{1,2}$ 凶
}

\begin{abstract}
Fertilizers are utilized to increase productivity through improved crop growth and yield potential. However, steady declining availability of synthetic fertilizers is becoming a growing concern to the World's food production industry. At the same time, there is increasing evidence that non-optimal (not applied at the right time and either at too high or too low dosages) applications of fertilizers may adversely affect the biochemical, physiological and morphological characteristics of crop plants, which in turn can adversely influence their resistance and/or increase their host suitability to pests. In this mini review, we discuss studies of spider mites (Acari: Tetranychidae) and their natural enemies to argue that, as part of a precision agriculture approach with temporally and spatially targeted applications, there is clear justification for more applied and basic research into smart-use of fertilizers as part of crop protection and research into "plant medicine".
\end{abstract}

Keywords: integrated pest management; spider mites; potassium; nitrogen; natural enemies

\section{Introduction}

Fertilizers are utilized to increase agricultural and horticultural productivity through improved crop growth

Received: 12 May 2014 / Accepted revised version: 25 July 2014 / Published online: 19 August 2014

(C) Horizon e-Publishing Group

CITATION

West, K., \& Nansen, C. (2014). Smart-use of fertilizers to manage spider mites (Acari: Tetrachynidae) and other arthropod pests. Plant Science Today, 1(3), 161-164. http://dx.doi.org/10.14719/pst.2014.1.3.56

\section{AUTHORS' AFFILIATIONS}

1 The University of Western Australia, School of Animal Biology, The UWA Institute of Agriculture, 35 Stirling Highway, Crawley, Perth, Western Australia 6009, Australia

2 State Key Laboratory of Crop Stress Biology on the Arid Areas, and Key Laboratory of Northwest Loess Plateau Crop Pest Management of Ministry of Agriculture, Northwest A\&F University, Yangling, Shaanxi, 712100, China

CORRESPONDENCE

Christian Nansen, Phone: + 61 (0) 86488 4717, Fax: +61 (0) 86488 7354, Email: christian.nansen@uwa.edu.au and yield potential. In this mini review, we discuss studies of spider mites (Acari: Tetranychidae) and their natural enemies to argue that, as part of a precision agriculture approach with temporally and spatially targeted applications, there is strong justification for more applied and basic research into smart-use of fertilizers as part of crop protection and research into "plant medicine". Growing empirical evidence supports the hypothesis that effective management of crop nutritional content (i.e. through spatio-temporal timing of fertilizer applications) may be a strategy to minimize crop losses due to pest infestations (Altieri \& Nicholls, 2003; Amtmann, Troufflard, \& Armengaud, 2008; Culliney \& Pimentel, 1986; Zehnder et al., 2007). Such a strategy was originally proposed more than 60 years ago (Haseman, 1950) and might be of considerable interest to a wide spectrum of growers and consumers with concerns about current reliance and dependence on pesticide applications (Nansen \& Ridsdill-Smith, 2013).

Spider mites. Many species of mites cause severe leaf damage to a wide range of agricultural and horticultural crops and trees (Gerson \& Weintraub, 2012). Two-spotted spider mites (Tetranychus urticae, Koch) are of great economic concern (https://edis.ifas.ufl.edu/in307), reportedly infesting over 1,100 plant species worldwide (Grbic et al., 2011). Females of two-spotted spider mites complete a generation in 2 to 3 weeks and lay more than 100 eggs in their life time (Gerson \& Weintraub, 2012). It is quite noteworthy that spider mite infestations are almost always associated with crops grown under moderate to severe levels of abiotic stress or unbalance induced by: 1) drought [sorghum, Sorghum bicolor (L.) Moench (Stiefel, Margolies, \& Bramel-Cox, 1992), soybean, Glycine max L. (Klubertanz, Pedigo, \& Carlson, 1990), Cowpea, Vigna unguiculata (L.) Walp (Abdel-Galil, Amro, \& Abdel-Moniem, 2008), and maize (Zea mays L.) (Perring, Holtzer, Toole, \& Norman, 1986; Toole, Norman, Holtzer, \& Perring, 1984)], or 2) fertilizer (Amtmann et al., 2008; Chen et al., 2007; Garman \& Kennedy, 1949; Machado et al., 2000; Rodriguez, 1951; Rodriguez \& Neiswander, 1949). In other words, risk of spider mite infestations may 
be partially mitigated by minimizing the risk of crops growing under conditions with abiotic stress or unbalance. Spider mite population dynamics are favored by hot and dry conditions (Perring et al., 1986), so concerns are being raised about a possible future increase in crop losses by spider mites as a result of climate change (Martini, Kincy, Vaughn, Dever, \& Nansen, 2013). An important challenge regarding effective spider mite control is that, according to the Arthropod Pesticide Resistance Database (APRD, http://www.pesticideresistance.org/), two-spotted spider mites have developed resistance to 93 active ingredients. The concerning ability of two-spotted spider mites to develop pesticide resistance has been known for over four decades (Helle \& Overmeer, 1973). It is therefore critically important to identify pest management strategies with reduced reliance on miticides.

Crop fertilization and host plant resistance. There are a wide range of complex interactions between crop fertilization and the host plant resistance of crops to arthropod pests. Crop fertilization directly influences digestibility (thickness of cell walls and content of structural compounds, such as, lignin and cellulose), nutrient content, and the synthesis of defense compounds (e.g. antioxidants, alkaloids, terpenoids, phytoalexins, flavenoids, etc). Low digestibility and nutrient content adversely affect arthropod growth and fitness, and higher plant contents of constitutive and inducible defense compounds also reduce arthropod growth and fitness. As an example, Amtmann et al. (2008) provided an excellent review of the role of potassium fertilization on host plant resistance, and showed that there is generally a positive association between potassium fertilization and host plant resistance. Altieri and Nicholls (2003) thoroughly reviewed the role of nitrogen and showed that there is generally a negative association between nitrogen fertilization and host plant resistance. It is important to highlight that the interactions between crop fertilization and the host plant resistance of crops are typically non-linear (so too much fertilizer may be as detrimental as too little) and influenced by crop growth stage and physical soil characteristics, such as $\mathrm{pH}$. Another example is the article by Huberty and Denno (2004), which outlines an intriguing hypothesis about how "pulsed drought stress" affects the availability of nitrogen. Therefore the incorporation of a fertilization regime into a pest management strategy needs to be considered in the context of other potential stress factors, such as, water availability.

Crop fertilization and host selection by spider mites. Numerous studies have demonstrated that fertilizer regimes can affect crop susceptibility to spider mites (Acari: Tetranychidae). Rodriguez (1951) conducted a very detailed study of relationships between experimental fertilization regimes applied to tomato plants (Solanum lycopersicum L), mineral uptake in leaves, and spider mite population development. The main conclusions from this excellent study were that there are complex interactions between minerals and that spider mite population development: 1) was negatively correlated with nitrogen, sulfur, and boron fertilization, 2) showed a bell-shaped response to phosphorous, 3) showed a positive response to silicon, magnesium and potassium, and 4) was unaffected by calcium. Despite the negative effect of nitrogen, Rodriguez (1951) referred to earlier studies demonstrating positive association between spider mite infestation and fertilizer applied (Garman \& Kennedy, 1949; Rodriguez \& Neiswander, 1949), and showed that spider mite populations doubled when the concentration of all the major elements in the nutrient solution was doubled. Chow, Chau, and Heinz (2009) also studied interactions between soil fertilization and spider mite development. They found that the leaf content of phosphorous in cut roses (Rosa hybrida L) increased in response to increased nitrogen fertilization, but this increase did not cause significant increase in population densities of spider mites. However, Chow et al. (2009) found that spider mite densities were positively correlated with levels of nitrogen fertilization. Chen et al. (2007) found a positive correlation between nitrogen and phosphorous concentrations in three foliage strata of ivy geranium, Pelargonium peltatum (L.) and within-plant distribution of spider mites. The abovementioned studies were all conducted under experimental lab and/or greenhouse conditions. However under field conditions, Machado et al. (2000) suggested that "hot spots" with high spider mite infestations in maize fields were associated with drought stress and plants growing in parts of fields with high levels of $\mathrm{NO}_{3}-\mathrm{N}$ in soils. Thus, there is strong evidence of a positive developmental response by spider mites to nitrogen-rich crops.

Based on choice experiments with excised leaf pieces (bio-response) and macro-element analyses, Nansen, Sidumo, Martini, Stefanova, and Roberts (2013) conducted multivariate analysis and showed that, among the main nutritional elements, potassium content showed the strongest correlation with spider mite bio-response. Nansen et al. (2013) found a strongly negative effect of leaf potassium content and spider mite bio-response. The latter result is corroborated by a review of over 2,000 studies regarding effects of potassium on pest and disease incidence in plants, in which Perrenoud (1990) found that in $63 \%$ of these studies, application of potassium led to a decrease in pest pressure.

Predatory Insect Preferences. Predatory mites, such as Phytoseiulus persimilis (Acarina: Phytoseiidae), have been utilized as an efficient and natural form of pest management for more than 100 years (Shimer, 1868). However, the performance of predatory mites as control agents of spider mites may be indirectly affected by fertilizer applications. Chow et al. (2009) found that 
reduced nitrogen fertilization combined with releases of predatory mites provided almost twice as effective control of two-spotted spider mites as predatory mites alone. Thus regarding horticultural production of cut roses, Chow et al. (2009) concluded that use of predatory mites as biological control agents was substantially aided by reducing plant fertilization to $10 \%$ of the recommended level without loss of productivity. Walde (1995) assessed the tri-trophic interaction between nutritional qualities of apple trees, the developmental rates and density of a phytophagous mite (Panonychus ulmi) and its natural predatory mites (Typhlodromus pyri and Zetzellia mali). Both predators had a greater impact on prey populations when nitrogen fertilizer levels applied to apple trees were low. Walde (1995) concluded that the increased population growth of P. ulmi on trees subjected to higher nitrogen was attributed to proportionally higher growth rates by the prey. This may explain the increased effectiveness of predatory mites in reducing spider mite infestations in plants fertilized at only $10 \%$ of the recommended level (Chow et al., 2009).

Although we are unaware of studies supporting this claim, it seems possible that the nutritional quality of host plants may partially affect the nutritional quality of spider mites as prey for the predatory mites. In a recent study, Prager, Martini, Guvvala, Nansen, and Lundgren (2014), examined the choice feeding behavior of predatory mites and demonstrated that spider mites cultivated on maize plants expressing Bt toxins (Bacillus thuringiensis) were significantly less preferred compared to spider mites cultivated on maize without the Bt toxins. The study by Prager et al. (2014) highlights that predatory mites are able to assess the quality of their prey and underscores the importance of more research into the tri-trophic interactions between the nutritional composition of host plants, feeding and development of herbivorous pests, and the performance of natural enemies.

Concluding remarks. Spider mites are cosmopolitan pests, and they cause significant losses in a wide range of food and fiber production systems. Effective management of this pest is hampered by very high levels of resistance to miticides. It is therefore important to develop alternative management practices with less reliance on miticides. Interestingly, spider mite infestations are frequently associated with host plant growing under moderate to severe levels of abiotic stress, and fertilizer applications greatly impact the occurrence of spider mite infestations and therefore the risk of them causing economic losses to crop production. We argue that, as part of a "preventive medicine approach" (Nansen et al., 2013), it is important to consider smart-use of fertilizers as part of existing pest management strategies. That is, spatial and temporal targeting and accurate dosing of fertilizers may improve crop health, boost resistance to arthropod pests and pathogens, and increase the effectiveness of natural predators in controlling pest populations. Subsequently, this will reduce the need for pesticide applications and minimize resistance of spider mites to various miticides.

\section{References}

Abdel-Galil, F. A., Amro, M. A. M., \& Abdel-Moniem, A. H. (2008). Effect of drought stress on the incidence of certain arthropod pests and predators inhabiting cowpea plantations. Archives of Phytopathology and Plant Protection, 40, 207-214. http://dx.doi.org/10.1080/03235400500424570

Altieri, M. A., \& Nicholls, C. I. (2003). Soil fertility management and insect pests: harmonizing soil and plant health in agroecosystems. Soil \& Tillage Research, 72, 203-211. http://dx.doi.org/10.1016/S0167-1987(03)00089-8

Amtmann, A., Troufflard, S., \& Armengaud, P. (2008). The effect of potassium nutrition on pest and disease resistance in plants. Physiologia Plantarum, 133, 682-691. http://dx.doi.org/10.1111/j.1399-3054.2008.01075.x PMid:18331404

Chen, Y., Opit, G. P., Jonas, V. M., Williams, K. A., Nechols, J. R., \& Margolies, D. C. (2007). Two spotted spider mite population level, distribution, and damage on ivy geranium in response to different nitrogen and phosphorus fertilization regimes. Journal of Economic Entomology, 100(6), 1821-1830. http://dx.doi.org/10.1603/0022-0493(2007)100[1821:TSM PLD]2.0.CO;2

Chow, A., Chau, A., \& Heinz, K. M. (2009). Reducing Fertilization for Cut Roses: Effect on Crop Productivity and Two spotted Spider Mite Abundance, Distribution, and Management. Journal of Economic Entomology, 102(5), 1896-1907. http://dx.doi.org/10.1603/029.102.0521

Culliney, T. W., \& Pimentel, D. (1986). Ecological effects of organic agricultural practices on insect populations. Agriculture, Ecosystems and Environment, 15(4), 253-266. http://dx.doi.org/10.1016/0167-8809(86)90124-6

Garman, P., \& Kennedy, B. H. (1949). Effect of soil fertilization on the rate of reproduction of the two-spotted spider mite. Journal of Economic Entomology, 42(1), 157-158.

Gerson, U., \& Weintraub, P. G. (2012). Mites (Acari) as a factor in greenhouse management. Annual Review of Entomology, 57, 229-247. PMid:21910634 http://dx.doi.org/10.1146/annurev-ento-120710-100639

Grbic, M., Van Leeuwen, T., Clark, R. M., Rombauts, S., Rouze, P., Grbic, V., ... Van de Peer, Y. (2011). The genome of Tetranychus urticae reveals herbivorous pest adaptations. Nature, 479(7374), 487-492. http://dx.doi.org/10.1038/nature10640

Haseman, L. (1950). Controlling insect pests through their nutritional requirements. Journal of Economic Entomology, 43, 399-401.

Helle, W., \& Overmeer, W. P. J. (1973). Variability in tetranychid mites. Annual Review of Entomology, 18, 97-120. http://dx.doi.org/10.1146/annurev.en.18.010173.000525

Huberty, A. F., \& Denno, R. F. (2004). Plant water stress and its consequence for herbivorous insects: a new synthesis. Ecology, 85, 1383-1398. http://dx.doi.org/10.1890/03-0352

Klubertanz, T. H., Pedigo, L. P., \& Carlson, R. E. (1990). Effects of plant moisture stress and rainfall on population dynamics of 
the two-spotted spider mite (Acari: Tetranychidae). Environmental Entomology, 19, 1773-1779.

Machado, S., Bynum, E. D. J., Archer, T. L., Lascano, R. J., Wilson, L. T., Bordovsky, J., ... Xu, W. (2000). Spatial and temporal variability of corn grain yield: site-specific relationships of biotic and abiotic factors. Precision Agriculture, 2(4), 359-376. http://dx.doi.org/10.1023/A:1012352032031

Martini, X., Kincy, N., Vaughn, K., Dever, J., \& Nansen, C. (2013). Positive association between thrips and spider mites in seedling cotton. Agricultural and Forest Entomology, 15(5), 197-203. http://dx.doi.org/10.1111/afe.12004

Nansen, C., \& Ridsdill-Smith, T. J. (2013). The performance of insecticides - a critical review. In S. Trdan (Ed.), Insecticides (pp. 195-232). Croatia: InTech Europe.

Nansen, C., Sidumo, A. J., Martini, X., Stefanova, K., \& Roberts, J. D. (2013). Reflectance-based assessment of spider mite "bio-response" to maize leaves and plant potassium content in different irrigation regimes. Computers and Electronics in Agriculture, 97, 21-26. http://dx.doi.org/10.1016/j.compag.2013.06.007

Perrenoud, S. (1990). Potassium and plant health (Vol. 3). Basel, Switzerland: International Potash Institute.

Perring, T. M., Holtzer, T. O., Toole, J. L., \& Norman, J. L. (1986). Relationships between corn-canopy microenvironments and Banks grass mite abundance. Environmental Entomology, 15, 79-83.

Prager, S. M., Martini, X., Guvvala, H., Nansen, C., \& Lundgren, J. G. (2014). Spider mite infestations reduce Bacillus thuringiensis toxin concentration in corn leaves and predators avoid spider mites that have fed on Bacillus thuringiensis corn. Annals of Applied Biology, 165, 108-116. http://dx.doi.org/10.1111/aab.12120

Rodriguez, J. G. (1951). Mineral nutrition of the two-spotted spider mite, Tetranychus bimaculatus Harvey. Annals of the Entomological Society of America, 44(4), 511-526.

Rodriguez, J. G., \& Neiswander, R. B. (1949). The effect of soil soluble salts and cultural practices on mite populations on hothouse tomatoes. Journal of Economic Entomology, 42, 511-526.

Shimer, H. (1868). Notes on the "Apple bark-louse" (Lepidosaphes conchiformis, Gmelin) with a description of a supposed new Acaris. Transactions of the American Entomological Society, 1, 361-374.

Stiefel, V. L., Margolies, D. C., \& Bramel-Cox, P. J. (1992). Leaf temperature affects resistance to the Banks grass mite (Acari: Tetranychidae) on drought-resistant grain sorghum. Journal of Economic Entomology, 85, 2170-2184.

Toole, J., Norman, L. J., Holtzer, M. T. O., \& Perring, T. M. (1984). Simulating Banks grass mite (Acari: Tetranychidae) population dynamics as a subsystem of a crop canopy-microenvironment model. Environmental Entomology, 13, 329-337.

Walde, S. J. (1995). How quality of host plant affects a predator-prey interaction in biological control. Ecology, 76(4), 1206-1219. http://dx.doi.org/10.2307/1940927

Zehnder, G., Gurr, G. M., Kühne, S., Wade, M. R., Wratten, S. D., \& Wyss, E. (2007). Arthropod Pest Management in Organic Crops. Annual Review of Entomology, 52(1), 57-80. http://dx.doi.org/10.1146/annurev.ento.52.110405.091337. 